\title{
Ecological Economy in the Context of Ecological Policy
}

\author{
$A K$ Namazov $^{1, *}, S A$ Kushelev $^{1}, L A$ Guzikova $^{1}$, and $K A$ Namazov $^{1}$ \\ ${ }^{1}$ Peter the Great Saint-Petersburg Polytechnic University Saint-Petersburg, Russia
}

\begin{abstract}
Ecologization of economic development is a pressing problem for the existence of mankind as the whole, world and national economies Targeted, consistent and concerted actions of all participants are the subject of ecological policy. The purpose of this article is to identify and justify the directions of improving national ecological policy in Russia, taking into account the relations of economy and ecology. The study is based on international documents and results of the Russian ecological policy investigation. The relevance of the adoption of the Environmental Code, which should include the regulation of the economic aspect, and the need to restore the system of environmental funds are substantiated. The necessity to develop a scientifically based system of indicators characterizing the relationship of ecology, economy and society is proved.
\end{abstract}

\section{Introduction}

Since the 80 s of the 20th century, there is a growing worldwide concern about the ongoing climate change and the speed of this change. The increase in the number and volume of harmful substances emissions into the atmosphere, which change the global climate, indicates a growing threat of rapid climate change [1]. Climate change, through a wide range of factors, affects world markets, has a direct impact on both the health and safety of people and the situation in various sectors of the economy, the state of the animal and plant world in all regions of the planet [2]. If current trends continue over the next 50 years, the average global air temperature may increase by $2-3^{\circ} \mathrm{C}$, which will lead to severe social and economic global scale consequences. Socio-economic and environmental impacts of climate change will be highly regionalized, which can cause conflicts for access to water and food resources, as well as for habitable lands [3].

Today, environmental problems are closely related to economic problems and are global in nature,. Ensuring sustainable economic development requires smart environmental management and the search for new economic tools stimulating ecological sustainability and natural resources recovery [4]. Over the past 20 years, more than a hundred countries have adopted strategies or programs for sustainable development, however, based on the results of changes in the ecological state, it has been determined that the principles of sustainable development could not be fully implemented in any country of the world [1].

The purpose of this article is to identify and justify the direction of improving ecological policy in Russia, taking into account the economic aspect.

\section{Data and methods}

The study is based on the official documents and contemporary scientific works on the ecological policy. The data used for quantitative analysis of the relations between ecological situation in Russian regions and other socio-economic characteristic reflected in ratings, the following data sources were used:

-ecological rating of the RF subjects (http://greenpatrol.ru/ru/stranica-dlya-obshchegoreytinga/ekologicheskiy-reyting-subektov-rf?tid=347);

-rating of socio-economic situation of the RF subjects

(http://www.riarating.ru/infografika/20180523/63009187 8.html);

-rating of investment attractiveness of Russian regions (http://www.ranational.ru/sites/default/files/analitic_article/IPR-606112018.pdf;)

-rating of innovative regions of Russia (http://iregions.org/images/files/airr18.pdf);

-rating of Russian regions by quality of life (https://basetop.ru/rejting-regionov-rossii-po-urovnyuzhizni-2019/);

-national Tourist Rating (http://rustur.ru/nacionalnyjturisticheskij-rejting-2018);

-rating of Russian regions on environmental and energy efficiency of business (https://interfaxera.ru/reitingi/2018/reiting-regionov-rossii/reitingfundamentalnoi-effektivnosti).

\footnotetext{
* Corresponding author: kuem@list.ru
} 


\section{Main Provisions and Results}

\subsection{Interrelations of Economy and Ecology}

The need to combine economic development with the environmental requirements has led to the emergence of a new branch in scientific knowledge - an ecological economy. It is based on a close relationship between the problems of economics and ecology. Ecological economics, as a branch of scientific knowledge, is an interdisciplinary field of study, in which both economists and ecologists are engaged. It covers issues of regulation the relationship between humans and nature, based on economic mechanisms that promote energy and resource saving, environmental pollution reducing, protecting biological diversity and overcoming rapacious consumers behavior.

Ecological economy is often called "green". According to the definition given in the UNEP reports, a green economy is an economy that improves people's well-being and ensures social fairness while significantly reducing risks to the environment and its degradation [5]. Important features of such an economy are [5]:

-efficient use of natural resources;

-safekeeping and increase of natural capital;

-pollution reduction;

-low carbon emissions;

-prevention of loss of ecosystem services and biodiversity;

-growth of income and employment.

The concept of a green economy is consistent with the concept of sustainable development, but does not replace it. Today, it is increasingly recognized that achieving sustainability is largely dependent on the greening of the economy. For Russia, the very concept of "green economy" is new, and it is not actually used in official documents. Nevertheless, the goals outlined by the country for the next 10-20 years largely correspond to the goals of transition to green economy. This is reflected in the general policy of natural resources consumption and environmental protection for the future, in acting legal and tax instruments [5]. The role of education and science in solving problems of safety and environmental protection is increasing [6].

Nature is the most important part of the country's wealth. Russia has enormous resources for the transition to a green economy: human, material, technological and natural. According to the World Bank estimates, the share of natural capital in the structure of Russia's national wealth is about $70 \%$, while human capital accounts for $20 \%$ and physical (produced, artificially created) $10 \%$ of total. In OECD countries, the natural capital constitutes only about $5 \%$, and the shares of human and physical capital are equal to $85 \%$ and $10 \%$ of, respectively [7].

The mutual influence of economics and ecology can be viewed from the standpoint of the human society interests and the quality of human life. The latter includes objective and subjective characteristics - health, life expectancy, environmental conditions, food, housing comfort, social environment, cultural and spiritual needs satisfaction, psychological comfort, etc.

The state of public health is determined by a combination of factors - genetic, environmental, sociostructural, economic, medical infrastructure, sanitary and hygienic, psychological, etc. However, their impact varies greatly depending on education, income level, type of economic activity of the working-age population, region of residence, availability of public economic resources. The above factors determine the inequality in the socio-economic situation of people and their level of health [8].

The greatest impact on the health of Russian inhabitants has the lifestyle $(50 \%)$, the second in the degree of influence on human health is environment $(25 \%)$, the third is heredity $(20 \%)$, medicine, that is, the quality of medical care and services, has the smallest impact (5\%) [9].

Today, the first ecological needs of human include clean air and water, natural and healthy food, and the preservation of habitat in its natural form. In addition, it is exclusively important to understand the nature of environmental crises, mistakes in interaction with the outside world, the need to correct the economy and politics. The significant influence of the environmental factor is also explained by its ability to exacerbate other causes of the public health deterioration [10].

In modern society, not only socio-economic and environmental factors affect the public health, but also human health has a direct impact on the economy of the country as a whole. It is well known that economic losses or the economic damage incurred by society and the state due to morbidity may be subdivided into direct and indirect.

Direct economic losses due to morbidity include the costs of medical care (outpatient, inpatient and rehabilitative treatment, sanitary and epidemiological services), payment of social insurance allowances for temporary disability and disability pension. Indirect economic losses due to morbidity, temporary or permanent disability or death, are exceed direct ones many times. They include losses caused by a drop in labor productivity and an increase in under-produced products, and, as a result, a decrease in total national income. According to research data, the share of direct economic losses accounts for only about $10 \%$ of the total economic damage from morbidity, while indirect losses account for almost $90 \%[11]$.

Since April 2008, the All-Russian Public Organization "Green Patrol" (www.greenpatrol.ru) publishes the Ecological Rating of the Russian Federation subjects. The rating is published four times a year: in winter, spring, summer and autumn. The ideology of the rating is based on the principles of sustainable development formulated in the Declaration of the United Nations Conference on Environment and Development (Rio de Janeiro, June 3-14, 1992).

To assess the correspondence of the environmental situation in the regions of the country as it manifests in the indicators of the Ecological rating with indicators of the socio-economic situation in the regions, their investment attractiveness, level of innovation, quality of 
Table 1. Correlation of the Russian Federation Regions Ratings with the Ecological Rating.

\begin{tabular}{|l|l|c|c|}
\hline \multicolumn{1}{|c|}{ Rating Composer } & \multicolumn{1}{|c|}{ Period } & Correlation ratio \\
\hline $\begin{array}{l}\text { Rating of socio-economic situation of the } \\
\text { RF subjects }\end{array}$ & RIA Rating & 2017 & -0.0584 \\
\hline $\begin{array}{l}\text { Rating of investment attractiveness of } \\
\text { Russian regions }\end{array}$ & $\begin{array}{l}\text { Expert RA; } \\
\text { National Rating Agency }\end{array}$ & -0.0029 \\
\hline Rating of innovative regions of Russia & $\begin{array}{l}\text { Association of Innovative Regions } \\
\text { of Russia }\end{array}$ & Q1 2019 & 0.0473 \\
\hline Rating of Russian regions by quality of life & RIA Rating Q1 2019 & 0.0390 \\
\hline $\begin{array}{l}\text { National Tourist Rating } \\
\text { Rating of Russian regions on } \\
\text { environmental and energy efficiency of } \\
\text { business }\end{array}$ & $\begin{array}{l}\text { Information Communications } \\
\text { Eith the journal "Rest in Russia" }\end{array}$ & 2018 & -0.1045 \\
\hline
\end{tabular}

human life, attractiveness for tourists, environmental and energy efficiency of business as they manifest in the respective ratings (Table 1), the correlation coefficients were calculated. The environmental rating for the period from December 1, 2018 to February 28, 2019 was used in the calculations.

From Table 1 it is evident that no significant correlations are revealed. This fact can not be clearly and unambiguously explained without additional thorough research. However, the following hypotheses related to environmental policy may be proposed:

1) the interrelationship of economy and ecology in the regions is not given due attention at the level of state regulation and state management;

2) business and the population of the country have no opportunities for influence the regional ecological situation through active improvement measures and / or for individual choice and movement to other regions;

3) the analyzed ratings do not provide an objective picture of the declared aspects, in particular, due to neglect or incorrect consideration of the environmental component.

\subsection{Improvement of Ecological Policy}

The Environmental policy worldwide is a means of improving the competitiveness of national economies, but in Russia, the system of environmental regulation is not developed. So, ecologization of Russia's economic development is one of the most important benchmarks for the modernization of the national economy [12].

There is no unified federal law on the ecological economy in the Russian Federation. The main areas of ecological legislation are:

1) environmental regulation (for example, the Law of the Russian Federation "On Environmental Protection", the Federal Law "On the Protection of Atmospheric Air");

2) safety regulation (for example, the Federal Law "On Fire Safety"; the Law of the Russian Federation "On the Protection of the Population and Territories from Technogenic Emergencies");

3) use of natural resource regulation (for example, Land Code, Water Code, Forest Code, Federal Law "On Production and Consumption Waste").
The main objectives of environmental policy currently facing Russia are:

1. Development and adoption of the Federal Law on the ecological ("green") economy in the Russian Federation and ensuring its effectiveness.

2. Development and adoption of the state program of transition to the ecological economy, which includes a reasonable set of indicators and their target values, which must be achieved by a certain time.

This program should include the subprograms:

on the electrification, aimed at providing electricity to the population and business, supporting domestic producers and reducing environmental pollution;

on the renewable energy sources.

3. The increase of state "green purchases". Government procurement is an effective mechanism for the entrepreneurship Government procurement is an effective mechanism for the entrepreneurship development. Every year billions rubles are spent on government purchases in various fields. However, in practice, tenders are won by those entrepreneurs offered the lowest price [13]. At the same time, the environmental friendliness of the goods / services production and their further impact on the environment are not taken into account. Thus, malicious production is encouraged. This situation needs to be corrected: the state should introduce mechanisms to check the negative impact of production and consumption of purchased goods / services on the environment [14].

4. Improving the taxation of enterprises developing eco-products, and enterprises with environmentally friendly production.

The task of the state is to create conditions for enterprises to use the least harmful technologies in production, if only because it is beneficial for them. Federal Law No. 7 "On Environmental Protection" establishes that the state provides support for environmentally friendly industries by providing tax incentives, but for the application of this law without rising discrepancies and litigations, regional legislations need to be corrected. Tax breaks should be established for enterprises using wastewater and air purifying plants; reducing emissions; using secondary raw materials.

5. Ecologization of agriculture. Russia is one of the largest producers of agricultural products in the world. 
"Greening" agricultural production will improve the quality of food for the domestic inhabitants and the competitiveness of agricultural products in foreign markets.

6. Restoration of pre-existing environmental funds. In 2010, the question was raised "about the reestablishment of environmental funds that existed in the 90 s of the 20th century and have positively manifested themselves as financing sources for environmentally significant activities" [15, p. 89]. But this issue was forgotten for several years again. The responsible approach to the issue which took place in the USSR where "environmental funds, on the one hand, were the financial instrument for the implementation of environmental and economic tasks, and on the other hand, were a legal entity ... managing these financial resources" [15, p. 90] should be restored.

It is worth noting that there is a global environmental fund whose main activity is to provide financing the expenditure for making the projects environmentally friendly.

\section{Conclusions}

Based on the degree and nature of threats to the existence of society, deriving from environmental changes, and current global trends in regulating the human impact on nature, the Russian Federation should develop an ecological policy that takes into account the multidimensional mutual influence of economic activity, ecology and society. The Ecological Code should become the central document establishing the principles and objectives of transition to ecological economy and the responsibilities distribution between federal, regional and local authorities and providing non-contradiction and comprehensive coverage of ecological regulation.

The ecological policy should include a complex measures aimed at reducing the severity of the problems already identified. To finance these measures, it is necessary to create a system of targeted environmental funds at the local, regional and federal levels.

It is necessary to develop a system of indicators which adequately, informatively and informally reflect the ecological situation in its relationship with socioeconomic processes. This task should be solved on an advanced scientific and technological basis with the participation of the academic and scientific community. The objectiveness of the indicators formation and their further evaluation can be facilitated with wide public involvement.

\section{References}

[1] IEA Energy, Technology Perspectives 2010: Scenarios and Strategies to 2050, OECD Publishing, Paris (2009). DOI: 10.1787/energy_tech-2010-en.

[2] G.T. Shkiperova, P.V. Druzhinin, Assessment of the impact of climate change on the economy of Russian regions, National interests: priorities and security, 34, 271, 43-50 (2014).
[3] A.O. Kokorin, S.N. Kuraev, Review of the Nicholas Stern report "The Economics of Climate Change" Moscow, 2007.

[4] S.S. Khamzina, B.K. Zhumabekova, Ecology and sustainable development, Moscow, Publishing House of the Academy of Natural Sciences, 330 (2016).

[5] S.N. Bobylev, Modernization and green economy: the world and Russia, Bulletin of the International Academy of Sciences (Russian section), 5, 11-13 (2012).

[6] K.R. Malayan, The role of education and science in solving problems of safety and environmental protection. Life Safety, 12, 216, 56-59 (2018).

[7] E.G. Rakovskaya, O.N. Rusak, N.G. Zanko, K.R. Malayan, "Green" economy in Russia: problems and prospects (2015) [Electronic resource]. Available at: http://spbftu.ru/site/upload/201511061638_Rakov skaja_Rusak_2015a.pdf (Accessed: 19.04.2019).

[8] V.S. Tapilina, Socio-economic status and public health, Sociological studies, 3, 126-137 (2004).

[9] A.P. Konstantinov, Ecology and health: the dangers are mythical and real, Ecology and Life, 12, 86-88 (2012).

[10] T.O. Tagaeva, V.M. Gilmundinov, L.K. Kazantseva, The nature of the influence of environmental factors on public health: regression analysis, Resource and institutional conditions for the formation of an innovative economy: Collective scientific monograph, Institute of economy and organization of industrial production SB RAS, Novosibirsk: Publishing House of the IEPP SB RAS, 91-108 (2015).

[11] K.A. Samutin, Public health as an integral part of the state's economic policy, Russian Journal of Entrepreneurship, 11, 209, 131-136 (2012).

[12] A.A. Sofronova, The national environmental policy of Russia and Finland as a form of public administration, Scientific notes of Petrozavodsk State University, 3-2, 148, 115-119 (2015).

[13] A.N. Kazantseva, The impact of the formation of a system of "green" public procurement on the development of the market for environmentally friendly products, Management consulting, 3, 99, 152-158 (2017).

[14] T.P. Smetanina, A.M. Vorotnikov, B.A. Tarasov, Organizational support of state green procurement in Russia: the formation of a market for environmentally friendly products, Bulletin of the Russian University of Cooperation, 1, 35, 6879 (2019).

[15] E.S. Navasardova, Environmental funds as sources of funding for environmentally significant events: historical and legal analysis, Legal research 1, 89-94 (2013). 